\title{
Combates pela educação operária: aspectos da reação católica à criação de Escolas Modernas no Brasil (1900-1920) ${ }^{1}$
}

\section{Combats on workers' education: aspects of the Catholic reaction against the creation of Modern Schools in Brazil (1900-1920)}

\author{
Isabel Bilhão²
}

\begin{abstract}
RESUMO
As propostas pedagógicas e os dados biográficos de Francisco Ferrer y Guardia já foram bastante estudados no contexto acadêmico brasileiro. No entanto, ainda carecem de maior investigação os argumentos e as estratégias utilizados pelos grupos opositores às suas concepções educacionais, especialmente os provenientes de membros da Igreja. Este artigo objetiva analisar alguns aspectos da reação católica à criação de Escolas Modernas no país nas primeiras décadas do século XX. Tal discussão embasa-se empiricamente em um encarte especial da Revista Vozes de Petrópolis, publicado em 1913. Pretende-se ampliar a compreensão dos embates em torno da educação operária no período inicial da República, refletindo especialmente sobre as estratégias argumentativas de religiosos que se propõem a combater a difusão da educação racionalista entre os trabalhadores.
\end{abstract}

Palavras-chave: educação operária; Escola Moderna; católicos; anarquistas.

\section{DOI: $10.1590 / 0104-4060.43357$}

1 As reflexões aqui apresentadas fazem parte de um projeto mais amplo de investigação intitulado Entre a fé e a razão: disputas de católicos e anarquistas pela educação operária (Espanha, Brasil e Argentina - 1891 a 1920), desenvolvido junto ao Programa de Pós-Graduação em Educação/Universidade do Vale do Rio dos Sinos (Unisinos), contando com financiamento do Edital Universal do Conselho Nacional de Desenvolvimento Científico e Tecnológico (CNPq).

2 Universidade do Vale do Rio dos Sinos. São Leopoldo, Rio Grande do Sul, Brasil. Av. Unisinos, nº 950, Cristo Rei, CEP: 93022-000.E-mail: ibilhao@unisinos.br 


\begin{abstract}
The pedagogical proposals by Francisco Ferrer y Guardia and his biography have been widely studied in the Brazilian academic context. However, the arguments and strategies of the opposite groups against his educational concepts, especially the ones from the Catholic Church, still require more investigation. This article aims to analyze some aspects of the Catholic reaction against the spread of Modern Schools in the country in the first decades of the twentieth century. The empirical basis of this discussion is a booklet published by Revista Vozes de Petrópolis, in 1913. We intend to extend the comprehension of the fight around education of workers in the early period of the Republic and think about the arguments of the clerics who fought against the diffusion of the rationalist education among workers.
\end{abstract}

Keywords: education of workers; Modern School; Catholics; anarchists.

\title{
Introdução
}

As ideias pedagógicas e a biografia de Francisco Ferrer já foram amplamente difundidas no Brasil por autores como Tragtenberg (1978), Luizzeto (1987), Gallo e Moraes (2005), Gallo (2013) e Castro (2014). No presente artigo não pretendo realizar uma abordagem biográfica nem discutir a importância ou o alcance das concepções de Ferrer em âmbito nacional. Minha intenção é tratar de um aspecto ainda pouco explorado nos estudos sobre o mundo do trabalho brasileiro no início do período republicano: a reação católica à divulgação da educação racionalista e à difusão de Escolas Modernas no país.

Esta análise tomará como exemplo um encarte especial da Revista Vozes de Petrópolis, de novembro de $1913^{3}$, intitulado 'Ferrer 'Mártir' ou 'patife'?', assinado pelo frei franciscano Pedro Sinzig. O opúsculo narra a participação do religioso em uma reunião organizada por três militantes anarquistas que, provenientes do Rio de Janeiro, se dirigiram a Petrópolis para difundir o ensino racionalista de Francisco Ferrer e buscar apoiadores para a fundação de uma Escola Moderna na cidade. O objetivo era propagandear que o religioso havia vencido uma acirrada discussão, demonstrado que Ferrer era um "patife" e não um "mártir" e conseguido impedir a fundação da escola.

Mesmo considerando o fato de existir, no período estudado, uma elevada incidência de analfabetismo - representando um obstáculo importante à divul-

3 A revista Vozes de Petrópolis, fundada por freis franciscanos na cidade de Petrópolis, Rio de Janeiro, circulou no período de 1908 a 2003. 
gação de ideias por meio da imprensa -, penso que a análise do documento pode auxiliar na observação dos esforços realizados e no tipo de argumentação utilizada por membros do clero católico na ofensiva à divulgação das concepções pedagógicas de Ferrer. Secundariamente, a discussão se utiliza de textos de jornais anarquistas como $O$ Sindicalista, de Lisboa, e $A$ Voz do Trabalhador, do Rio de Janeiro, para refletir, ainda que de forma indiciária, sobre as disputas em torno da instrução dos trabalhadores e seus filhos nas décadas iniciais do século XX.

Quando li pela primeira vez o opúsculo, minha reação foi de descrédito. Pensar que o religioso havia deixado a segurança de sua ordem e de sua rotina de trabalho para desafiar um grupo de militantes anarquistas, esgrimir ideias e, posteriormente, publicar um livreto no qual propagandeava sua vitória, pareceu-me inverossímil. Cabe esclarecer que na época eu desconhecia os dados biográficos do autor ${ }^{4}$. Ficou-me, contudo, a vontade de saber mais sobre este e outros embates em torno de Ferrer e suas concepções, especialmente aqueles relacionados à difusão da pedagogia racionalista no interior do mundo do trabalho brasileiro.

Minha curiosidade aumentou quando encontrei a resposta dada pelos militantes anarquistas a esse texto, comprovando que tal confronto havia de fato ocorrido, demandando inclusive que o veículo de imprensa da Confederação Operária Brasileira (COB), A Voz do Trabalhador, publicasse, em janeiro de 1914, um artigo intitulado "Palavras de um Franciscano", no qual o articulista desmentia a vitória do religioso e colocava em dúvida seus conhecimentos em relação à vida de Ferrer, indicando-lhe a obra Francisco Ferrer: alguns dados para a História e esclarecendo que "[...] nesse livreto a biografia do inesquecível mestre é feita com a máxima clareza". (A Voz do Trabalhador, $1^{\circ}$ jan. 1914, p. 2).

Retomei esses escritos no projeto de pesquisa acima mencionado, no qual busco analisar a educação operária nas décadas iniciais do século XX como um campo de disputas onde se enfrentaram diferentes grupos contendores, portadores das mais distintas concepções educacionais e político-ideológicas. Neste artigo priorizo a análise de um aspecto desse enfrentamento, organizando a discussão em três tópicos. No primeiro, retomarei brevemente alguns dados da vida e da obra de Ferrer para esclarecer os argumentos e acusações presentes no opúsculo católico, retomado no último tópico. No segundo tópico farei uma breve aproximação à conjuntura brasileira na qual foi produzido o documento estudado

4 Agradeço ao historiador Tiago Bernardon de Oliveira, por fornecer-me as primeiras informações sobre Pedro Sinzig. À medida que conheci sua vida e obra, percebi que esta era uma atitude bastante compatível com sua verve polemista. Sobre o personagem, ver, entre outros, Santos (2004 e 2006) e Carneiro (2002). 
e, no terceiro, analisarei a argumentação católica em oposição à disseminação da educação racionalista, presente no opúsculo "Ferrer 'Mártir' ou 'patife'?".

\section{Uma breve aproximação à biografia de Ferrer}

As disputas em torno da via e da obra de Ferrer, iniciadas enquanto ele ainda vivia, foram alimentadas por inúmeras publicações, biografias e homenagens e cresceram enormemente, em especial nos aniversários de seu falecimento. Esses textos circularam em diversos países e foram respondidos de maneira mais ou menos contundente por membros do clero católico. Ao público brasileiro, especialmente aos trabalhadores que tinham algum contato com o movimento operário, Ferrer foi apresentado por meio de periódicos e livretos, em sua grande maioria vindos da Espanha e de Portugal que então eram traduzidos, adaptados e transcritos, ou oferecidos no original, em gabinetes e clubes de leitura, nas redações dos jornais da imprensa militante e nas bibliotecas das Escolas Modernas ${ }^{5}$.

Um exemplo dessa produção é o resumo biográfico publicado pelo jornal lisboeta $O$ Sindicalista, que circulou em outubro de 1911, marcando a passagem do segundo aniversário da morte de Ferrer. A longa narrativa, estampada na primeira página do periódico, assim apresentava as décadas iniciais da vida do homenageado:

Francisco Ferrer y Guardia nasceu a 10 de janeiro de 1859, em Allella, perto de Barcelona. Seus pais, agricultores remediados eram monárquicos e profundamente católicos [...]. Dos 13 para 14 anos entrou como empregado numa casa de comércio de Barcelona, cujo chefe era francamente livre-pensador. Foi sob sua influência que se tornou anticlerical. Até os 21 anos a vida de Francisco Ferrer decorreu toda no trabalho e no estudo. Obteve então o lugar de revisor nos caminhos de Ferro do Norte da Espanha e desposou uma catalã, Teresa Sanmarti, com quem teve muitos filhos. (O Sindicalista, 13 out. 1911, p. 1) .

Observando-se um contexto mais amplo, percebe-se que a juventude de Ferrer transcorreu em um período no qual a Espanha passou por profundas

5 Uma discussão acerca da importância dessa circulação para o movimento operário pode ser encontrada em Bilhão (2008, p. 168-203).

6 A grafia das fontes jornalísticas foi atualizada. 
transformações, sobretudo pelo crescimento urbano e industrial, que favoreceu o associativismo operário. A época também foi marcada pela expansão das ordens religiosas na Península Ibérica, especialmente provenientes da França, devido à decretação das Leis Anticongregacionistas ${ }^{7}$, observando-se então a ampliação da ação social católica que se propunha a atuar na educação dos trabalhadores e seus filhos e a exacerbação tanto do clericalismo quanto do anticlericalismo ${ }^{8}$ naquele país. (ZORRILLA, 1987, p. 178; VIÑAO, 1993, p. 22).

O relato d'O Sindicalista informa ainda que, em 1884, Ferrer tornou-se maçom, iniciado na Loja Verdade, de Barcelona, e que dois anos depois participou de uma revolta contra a monarquia. Derrotada a insurreição, refugiou-se com a família em Paris, onde trabalhou como secretário do líder republicano espanhol, e igualmente exilado político, Manoel Ruiz Zorrilla, dedicando-se intensamente à propaganda republicana e anticlerical. Nessa época Ferrer também se tornou professor de Espanhol e passou a refletir sobre metodologias de ensino da língua, chegando a publicar um manual. (O Sindicalista, 13 out. 1911, p. 1).

Na França ele conheceu o educador Paul Robin (1837-1912), um dos principais expoentes do movimento de renovação dos métodos educacionais e divulgador do conceito de educação integral no interior da Associação Internacional dos Trabalhadores ${ }^{9}$. Entre as concepções de Robin estavam a defesa do desenvolvimento da criança em seus aspectos intelectuais, físicos e morais e a coeducação de meninos e meninas no mesmo espaço escolar, ainda um tabu na época. (GALLO, 2013).

Nesse período, somou-se ao anticlericalismo republicano, vivenciado por Ferrer na Espanha, o anticlericalismo educacional, uma vez que boa parte do discurso de renovação pedagógica, por ele compartilhado, opunha-se frontalmente aos métodos das escolas católicas. Ferrer começou a postular uma concepção denominada racionalista, defendendo o ensino das ciências naturais como centrais e um aprendizado ativo baseado na observação da natureza e das relações sociais. Assim como Robin, Ferrer defendia a coeducação de meninos e meninas no mesmo ambiente e a observação dos aspectos físicos, profissionais

7 As Leis Anticongregacionistas de Waldeck-Rosseau, em 1901, e Combes, em 1902, foram aprovadas na França, pelo Conselho de Ministros, durante a terceira república francesa (1873-1940), fazendo com que diversas congregações deixassem o país rumo à Península Ibérica e à América do Sul.

8 O movimento anticlerical pode ser definido tanto como a atitude de oposição ao poder temporal da Igreja, especialmente seus abusos políticos e econômicos, em diferentes contextos, quanto como a hostilidade ao catolicismo como religião ou ideologia. (RIEGELHAUPT, 1982, p. 1216). Conforme Valladares (2000, p.10), a palavra anticlerical se originou na França, por volta da década de 1850 .

9 Entre 1880 e 1894, Robin dirigiu o orfanato Prévost, nos arredores de Paris, onde buscou colocar em prática suas concepções de ensino. 
e ético-morais dos estudantes. Entretanto, Ferrer defendia ainda a coeducação das classes, ou seja, uma escola aberta não apenas aos trabalhadores, mas a todos que comungassem de seus ideais educativos. Esse modelo foi por ele e seus seguidores denominado de Escola Moderna. (GALLO; MORAES, 2005, p. 89; GALLO, 2013, p. 244).

Ainda em Paris, Ferrer separou-se da primeira esposa e passou a viver com Soledad Villafranca. No mesmo período, conheceu Ernestina Meunier, uma abastada discípula que lhe deixou, em 1901, uma herança capaz de financiar a fundação da primeira Escuela Moderna, criada no mesmo ano, quando retornou a Barcelona. Junto com a Escuela, foi fundada a editora Publicaciones de la Escuela Moderna, inicialmente com a finalidade de fornecer livros à nova instituição educativa. Entretanto, os editores observaram a existência de um público adulto, ligado a grupos livres de pensadores, sindicalistas, socialistas e libertários ${ }^{10}$, que demandava outras obras e autores, para as quais a Publicaciones tornou-se uma importante fornecedora.

Em maio de 1906, o governo espanhol mandou fechar a Escuela Moderna e decretou a prisão e o confisco dos bens de Ferrer, acusando-o de participação no atentado ao cortejo nupcial do Rei Afonso XIII ${ }^{11}$. Libertado em seguida, mudou-se para a França e depois para a Bélgica, onde fundou a Liga Internacional para a Educação Racional da Infância e retomou a publicação do Boletín de la Escuela Moderna, iniciando a internacionalização de suas duas linhas editoriais: a escolar e a de divulgação científico-racionalista. Essa internacionalização teve como resultados mais visíveis a ampliação de uma acirrada campanha em favor da renovação pedagógica e o crescimento do número de Escolas Modernas na Europa e na América. (VELÁZQUEZ; VIÑAO, 2010, p. 88-90). As atividades da Publicaciones foram interrompidas com a nova prisão e posterior execução de Ferrer que, tendo retornado à Catalunha em 1909, foi acusado de ser o mentor intelectual da "Semana Trágica"12, condenado à morte e fuzilado, juntamente com mais quatro líderes sindicais, em 13 de outubro do mesmo ano. (ULMANN, 1972).

10 Ferrer nunca se definiu como anarquista e suas concepções pedagógicas foram apropriadas tanto na Europa quanto no Brasil, por diversas correntes ideológicas que militavam no meio operário, especialmente pelos socialistas e anarquistas.

11 O autor do atentado, o anarquista Mateo Morral (1880-1906), havia trabalhado como bibliotecário na Escuela Moderna. Devido a essa ligação, Ferrer foi indiciado como mentor intelectual do ato. (GALLO, 2013, p. 244).

12 Rebelião popular, ocorrida em Barcelona, de 26 de julho a 02 de agosto de 1909, propagada a partir de uma greve geral contra o envio de tropas espanholas ao Marrocos, que se caracterizou pelo incêndio de conventos, igrejas e outros prédios religiosos e na qual ocorreram confrontos diretos de trabalhadores e populares com as forças governamentais. (ULMANN, 1972). 
A prisão de Ferrer fez com que militantes de distintas correntes ideológicas, identificados com suas propostas pedagógicas, promovessem campanhas por sua libertação em vários países e a manutenção da sentença acabou servindo de base para a construção de um discurso que o apresentaria como mártir da instrução operária. Tal imagem foi reforçada quando, em 29 de dezembro de 1911, a justiça espanhola inocentou-o oficialmente dos crimes que lhe eram imputados e devolveu seus bens à família. (GALLO, 2013, p. 249). Ainda em 1911 a editora Publicaciones retomou suas atividades e a publicação do Boletín de la Escuela Moderna. No ano seguinte foi publicada a obra Escuela Moder$n a$, de autoria de Ferrer, que se tornou uma referência para seus seguidores em diversas partes do mundo.

No Brasil não foi diferente. Grupos militantes de distintas correntes ideológicas, entre eles, anarquistas e socialistas, embora divergindo em muitos aspectos relacionados às concepções e formas de atuação, tendiam a encontrar no anticlericalismo e na defesa da educação operária importantes pontos de convergência e muitos deles juntaram-se aos protestos internacionais contra a condenação de Ferrer.

\section{A jovem República brasileira: uma arena de confrontos}

O período conhecido como Primeira República caracterizou-se pelo federalismo político, pelo liberalismo econômico e por uma noção meramente formal de representatividade, ao manter a proibição do voto aos analfabetos e negar direitos políticos aos estrangeiros, importante parcela do operariado daquele momento ${ }^{13}$. Além disso, a aprovação no Congresso Nacional de leis extremamente repressivas, como a 1.641, de $1907^{14}$, e o tratamento cotidiano da questão social como "caso de polícia", ou a simples negação de sua existência, demonstram as dificuldades de organização e resistência que os trabalhadores enfrentavam para garantir direitos mínimos em uma sociedade na qual as marcas do regime escravista, há pouco abolido, ainda estavam muito presentes.

No âmbito educacional, a concepção federativa e liberal do Estado permitiu ao Governo Federal legar aos estados e municípios grande parcela de autonomia

13 Ao longo do período o percentual de eleitores nos pleitos presidenciais manteve-se em menos de $1,5 \%$ da população, excetuando-se as disputas de 1910 e 1930 que alcançaram, respectivamente, $3,2 \%$ e $5,7 \%$ de votantes. (CARVALHO, 2001).

14 Também conhecida como Lei Adolfo Gordo, por se tratar do nome do deputado propositor, permitia a sumária expulsão dos estrangeiros considerados perigosos à segurança pública. 
nos assuntos escolares ${ }^{15}$, incluindo-se aí a possibilidade de constituição ou não de redes de ensino, e também abriu amplos espaços para as iniciativas educativas fora do âmbito estatal. Algumas delas remetem a uma longa tradição, como no caso das escolas confessionais católicas, outras ocorreram devido à iniciativa de indivíduos ou grupos que, imbuídos de diversos saberes e visões de mundo, criaram escolas pelos mais variados recantos. Algumas dessas instituições visavam o público operário, crescente nos centros urbanos do país.

Dentre os grupos que se incumbiram da instrução dos trabalhadores no Brasil, nenhum outro se preocupou, de forma tão sistemática, com a difusão da proposta pedagógica de Ferrer quanto o dos anarquistas ${ }^{16}$. Educadores e divulgadores do ensino racionalista, como Polydoro dos Santos e Zenon de Almeida, em Porto Alegre; João Penteado e Edgard Leuenroth, em São Paulo; Maria Lacerda de Moura e José Oiticica, no Rio de Janeiro, ocuparam grande quantidade de páginas em jornais militantes para defender a Escola Moderna, colocando-se frontalmente contra o pensamento católico e, juntamente com outros militantes, esforçaram-se por criar escolas em distintas localidades. Algumas chegaram a funcionar por certo tempo, outras tiveram caráter bastante efêmero. O método preferido por eles era "a propaganda pela palavra", tanto oral quanto escrita. Assim, o estímulo à alfabetização e à leitura se constituíam em temas centrais em seus esforços de propaganda. (PERES, 2010, p. 104-105).

Outra significativa modificação, advinda com a República, foi a separação Estado-Igreja. Tal medida causou, ao mesmo tempo, alívio e apreensão à hierarquia eclesial: "Alívio porque os novos tempos permitiam uma liberdade de ação ante o poder temporal há muito reclamada e apreensão porque o projeto da nova Constituição [1891] apresentava propostas evidentes de limitação da esfera de ação da Igreja Católica”. (HERMANN, 2003, p. 123). Uma das principais era a laicização do ensino público ${ }^{17}$. Por outro lado, liberada das obrigações e do controle do poder temporal, a Igreja Católica no Brasil pôde fortalecer sua hierarquia eclesial, dar combate mais contundente ao que considerava como erros contemporâneos, ou seja, às concepções racionalistas e anticlericais e aprofundar a ofensiva contra o ensino estatal ou de outros grupos concorrentes. Tal situação tornou necessário, além de renovar as antigas ordens religiosas, trazer para o Brasil congregações católicas europeias que pudessem estabelecer vínculos mais

15 Uma análise sobre a expansão da educação escolar ao longo da Primeira República pode ser vista em Schueler e Magaldi (2009).

16 O termo anarquista é aqui atribuído a militantes de variados matizes, que postulavam versões difusas do pensamento ácrata, ao qual tinham acesso por meio de autores como Proudhon, Malatesta, Kropotkin, Bakunin e, especialmente, de tradutores e divulgadores de suas obras.

17 A Constituição Federal de 1891, em seu artigo $72, \S 6^{\circ}$, definiu que seria "leigo o ensino ministrado nos estabelecimentos públicos". 
sólidos com a Cúria Romana. (SOUZA, 2002). No final do século XIX e início do XX, chegaram ao país religiosos que se envolveram em obras assistenciais, associações operárias e escolas para os trabalhadores. (DALLABRIDA, 2005).

Frei Pedro Sinzig, mencionado no início desse texto, foi um desses religiosos. Chegado da Alemanha, ainda noviço, em 1893, depois de algumas andanças pelo Brasil, fixou-se na cidade de Petrópolis, no estado do Rio de Janeiro, e ali dirigiu, entre 1908 e 1913, a editora fundada por sua congregação, a Vozes de Petrópolis, e editou a revista homônima até 1920. (SANTOS, 2004). Por meio da revista travou calorosas polêmicas com aqueles que, a seu ver, ameaçavam a "boa imprensa". Além disso, o religioso participou da modernização da gráfica que passou a produzir materiais didáticos, inicialmente para a escola gratuita de São José e, posteriormente, para várias outras escolas católicas pelo Brasil. Também escreveu uma grande quantidade de obras (romances, contos e novelas) de caráter doutrinário ${ }^{18}$. (SANTOS, 2004, p. 9; CARNEIRO, 2002 p. 45).

\section{O encarte "Ferrer 'Mártir' ou 'patife'?": um exemplo da contraofensiva católica}

Pedro Sinzig vinha, de longa data, travando em seus livros e na Revista Vozes uma verdadeira cruzada contra todas as posturas ou ideologias consideradas ofensivas ao pensamento católico. O encarte "Ferrer 'Mártir' ou patife?", brevemente apresentado no início deste artigo, faz parte desse combate. Nele, o franciscano apresentava uma versão da biografia de Ferrer muito distante daquela que o definia como mártir da educação operária. Segundo ele, sua participação na reunião dos trabalhadores em Petrópolis teve como principal objetivo provar que Ferrer era um "patife que não valia a carga de chumbo que levou!"19. Com esse intuito, o polemista utilizou-se das informações que julgava possuir sobre o assunto, organizadas conforme as estratégias retóricas de seu tempo. Vejamos alguns dos argumentos por ele mobilizados.

Em relação à infância de Ferrer, Sinzig salienta que este “[...] foi educado piedosamente, mas entregue, aos 13 anos de idade, a um patrão ateu, que em vez

18 Sua obra mais conhecida foi o livro Através dos Romances: Guia para as consciências, de 1915, no qual estabelecia uma classificação crítica para as obras literárias em circulação no período visando orientar a leitura das famílias católicas. (SANTOS, 2004, p. 9; CARNEIRO, 2002, p. 45).

19 Todas as citações referentes à argumentação de frei Pedro Sinzig foram retiradas do opúsculo “Ferrer 'Mártir' ou 'patife'?”. Encartado na revista Vozes de Petrópolis, 1º nov. 1913. Foram mantidos todos os grifos do original. Só será realizada nova referência quando se tratar de outra fonte. 
de ensinar-lhe bem seu ofício, corrompeu-o". Por essa linha de pensamento, o anticlericalismo de Ferrer é atribuído não à sua educação familiar, mas ao fato de que, ao ser colocado muito jovem no mundo do trabalho, deparou-se com ideias corruptoras, que acabaram por desviá-lo da formação católica. Nessa passagem, o texto toca em uma questão muito cara ao pensamento social católico do período, fortemente influenciado pela encíclica Rerum Novarum ${ }^{20}$, que recomendava que a criança não deveria " [...] entrar na oficina senão quando a idade tenha desenvolvido nela as forças físicas, intelectuais e morais; do contrário, como uma planta ainda tenra, ver-se-á murchar com demasiada precocidade e dar-se-á cabo de sua educação". (Rerum Novarum, 1941, p. 24).

Outra estratégia utilizada pelo religioso foi a de colocar em dúvida a aproximação de Ferrer ao operariado. Em suas palavras, "Os Srs. operários a pensar que ele era operário e, longe de ser um deles, era um capitalista e milionário, um destes capitalistas hoje tão atacados". Semear a dúvida em relação às reais condições econômicas de Ferrer poderia ser um argumento poderoso para colocar em xeque a identificação dos trabalhadores com o pedagogo, ameaçando sua legitimidade e possibilitando a ruptura de vínculos de reconhecimento.

Cabe esclarecer que nem Ferrer nem seus divulgadores jamais o apresentaram como "operário". Pelo contrário, uma das características marcantes dessa fase da organização dos trabalhadores é justamente a colaboração de indivíduos de "fora da classe", especialmente de intelectuais engajados. O religioso elaborou, portanto, uma seleção de acusações que não tinham necessariamente respaldo na realidade. Entretanto, essa é, diga-se de passagem, uma característica comum da polêmica, que pode ser definida como "[...] um gênero literário que combina a novidade do espaço público, valores tradicionais como honra e duelo, e boa dose de personalismo". (VENTURA, 1991, p. 12). Nas contendas jornalísticas do período, os polemistas podiam se valer, em doses mais ou menos equivalentes, tanto de argumentos considerados científicos e de "falas de autoridades", quanto de ataques diretos à honra e à moral de seus oponentes ${ }^{21}$.

Com relação a esse último aspecto podem-se observar mais dois exemplos. O primeiro coloca em dúvida a honestidade de Ferrer em sua relação com Ernestina Meunier. Segundo Pedro Sinzig, o pedagogo teria se aproximado "fingindo-se piedoso" e, com isso, conseguido que ela contribuísse "com 16.000 francos anuais para a fundação dum asilo de órfãos". Mas, ao invés disso, Ferrer teria deixado "cair os 16.000 francos na sua própria bolsa, gastando-os para

20 Publicada em maio de 1891, em linhas gerais, reforçava o direito à propriedade privada e a necessidade de harmonia entre as classes sociais, condenava as ideias socialistas e anarquistas e apontava o corporativismo como forma de resolução dos problemas sociais.

21 Sobre a polêmica no meio sindical pode-se ver o trabalho de Schmidt (2000). 
suas escolas modernas". E arremata exclamando "O mártir, o herói, o nobre chefe de família, roubando!". O segundo exemplo de ataque à honra de Ferrer é direcionado à sua vida familiar: "O grrrrrrande [sic] Ferrer, aliás, procurou Soledad Villafranca, fazendo-a sua amante". Acrescentando à condenação o fato de "Ferrer, vivendo principescamente com Soledad, tratar tão infamemente a própria mulher, e deixar quase morrer à míngua, com dois filhos naturais, a filha que estava trabalhando numa fábrica de biscoitos de Paris".

Os argumentos mobilizados por Pedro Sinzig apontam para a intenção de "desmascarar" Ferrer a partir de uma dupla denúncia. A primeira, de sua conduta moral reprovável, marcada pela desonestidade, ao aproveitar-se da ingenuidade de sua benfeitora e por abandonar sua família. A segunda, de sua conduta pecaminosa, uma vez que Ferrer rompeu os laços matrimoniais, considerados sagrados pela Igreja. Entretanto, tal argumentação só seria eficaz se a audiência a qual se dirigia compartilhasse de valores e princípios morais semelhantes aos seus, o que muito possivelmente era o caso da maior parte dos que haviam se dirigido ao local pelo interesse em ouvir falar sobre a fundação de uma nova escola na cidade. Portanto, acusar Ferrer publicamente de desonesto e pecador, provavelmente fosse uma estratégia em consonância com a conduta moral amplamente aceita pelo grupo social ao qual o franciscano se dirigia e pelo qual travava sua batalha de convencimento, tornando seus ataques suficientemente fortes para por em xeque a honradez de Ferrer, atributo sem o qual ele jamais poderia ser tomado como um modelo para o operariado ${ }^{22}$.

Todavia, num embate como esse, além de atacar o oponente, deve-se defender a própria causa. Em uma passagem posterior do texto, ele lança o seguinte desafio: “[...] atacaram hoje, repetidas vezes, a Igreja Católica e seus ministros. Pois senhores, vejam por si, quem é que faz mais pelo operariado: a Igreja ou os anarquistas?". Acrescentando, em seguida, “[...] lá está meu confrade frei Paulo, que todos os dias ensina vossos filhos na escola gratuita que dirige. Nesta e na outra que temos em Petrópolis, mais de 500 meninos. As irmãs de Santa Catarina ensinam centenas de meninas. Gratuitamente!". Para então repetir o questionamento: "Onde estão as escolas que os srs. anarquistas fundam e mantém? [...] Os anarquistas que vos enchem os ouvidos de escola moderna, a ensinar o assassinato, ao menos mantém algum orfanato?"

As referências de Pedro Sinzig às escolas mantidas pela ordem Franciscana e pela congregação feminina de Santa Catarina, em Petrópolis, estão em consonância com os esforços que a Igreja Católica vinha fazendo para propagar sua atuação no interior de uma rede escolar em formação, tanto estimulando

22 Uma análise sobre os atributos de honradez no movimento operário pode ser encontrada em Silva Júnior (1998). 
professores católicos a prestarem concurso nas escolas públicas, visando combater "por dentro" o ensino leigo (DALLABRIDA, 2005, p. 79), quanto na ampliação do número de escolas confessionais que, em princípios do século XX, voltaram-se também aos trabalhadores e seus filhos.

Mas os educadores católicos, da mesma forma que seus opositores, se deparavam com uma difícil realidade a ser vencida, a de que aproximadamente $85 \%$ da população do país era analfabeta. (PAIVA, 1973, p. 70). Portanto, naquele período, a expansão da rede escolar católica, e a consequente luta contra o analfabetismo, também pode ser vista como um meio de dotar as famílias proletárias de instruções e argumentos que lhes possibilitassem melhor resistir tanto aos apelos de ideologias rivais quanto aos excessos laicizantes do Estado. Além disso, mesmo defendendo o ensino religioso e tentando manter os fiéis afastados de ideias consideradas perigosas, as instituições católicas começavam a reconhecer a necessidade de preparar seus seguidores para um novo mundo do trabalho, urbano e industrial, em ascensão.

Retornando ao opúsculo, observamos que Pedro Sinzig toca em outra questão candente na época. Em suas palavras: “[...] os anarquistas vos pregam, levianamente, a greve. Ora, aparecem eles para conseguir-vos um novo emprego quando demitidos?". Acrescentando então, "Eles nunca foram vistos nos escritórios dos patrões, para falarem por vós, enquanto mais de cem de vossos camaradas deve sua readmissão na fábrica a meus confrades de sacerdócio". Nesse tópico, a argumentação gira em torno da condenação dos métodos anarquistas, especialmente aqueles ligados à ação direta, greves e boicotes, na militância sindical. A questão em disputa parece ser a de quem efetivamente faz mais pelos trabalhadores e qual estratégia é a mais eficaz diante da realidade em que vivem. Ou seja, o religioso, valendo-se de certo pragmatismo argumentativo, lembra aos ouvintes e leitores que a influência dos representantes da Igreja junto aos patrões é bem maior do que a do grupo de anarquistas a quem combate.

A eficácia de tal argumentação, contudo, só seria alcançada se ela não negasse a realidade daqueles a quem se dirigia. Nesse sentido, frei Pedro ponderava: "[...] lamento não termos, em proteção do operariado, uma legislação social. As condições dos operários são más, em parte péssimas", retomando em seguida o tom conciliatório, “[...] mas para melhorá-las não devem recorrer à violência”.

Estes aspectos da retórica do franciscano também estão consoantes às características do pensamento social católico, pós-Rerum Novarum. Conforme salienta Davidson Amaral, "[...] nas décadas finais do século XIX, a Igreja Católica precisou não apenas reconhecer a existência de uma 'questão social', mas também pensá-la como um problema estrutural, inerente à lógica capitalista". (AMARAL, 2007, p. 28). Ao longo do pontificado de Leão XIII (1878-1903), parte dos pensadores católicos passou, por um lado, a reconhecer os problemas 
econômicos e sociais e, por outro, a condenar a luta de classes como caminho para sua solução. Naquele contexto, a Igreja precisou não apenas lutar pelo espaço perdido com a expansão das ideias racionalistas, socialistas e anarquistas, como também se reafirmar como irradiadora de uma "consciência moral do mundo". (SOUZA, 2002, p. 37), postulando-se como instituição normatizadora da lógica social que se estabelecia, procurando, entre outras medidas, arbitrar as relações entre patrões e trabalhadores. Pedro Sinzig, portanto, lançou mão de um arcabouço teórico condizente com uma interpretação de mundo que vinha ganhando espaço no interior do catolicismo.

Todavia, em relação ao ensino racionalista e à expansão das Escolas Modernas são feitas apenas três menções ao longo do texto, todas reiterando que Ferrer e seus seguidores "[...] ensinava[m] e recomendava[m] o uso das bombas de dinamite e dos punhais envenenados e pregavam o assassinato". Tal economia de palavras, no entanto, não parece se dever ao desconhecimento do religioso em relação ao tema, na época já bastante difundido e discutido, mas antes a uma estratégia de silenciar para não alardear, evitando assim colaborar com o inimigo. Essa hipótese pode ser embasada no fato de que ao falar sobre as concepções racionalistas das escolas modernas, mesmo que para condená-las, frei Pedro precisaria entrar no perigoso terreno do cientificismo e, nesse caso, toda cautela era necessária.

A simples menção às concepções racionalistas de ensino poderia despertar o interesse dos ouvintes e leitores, uma vez que essas haviam se tornado um importante argumento legitimador por parte dos educadores anarquistas. Estes defendiam a primazia da razão e o emprego da racionalidade pedagógica, num momento em que importantes parcelas da população começavam a enxergar na difusão desses preceitos um remédio eficaz contra o atraso econômico e social do país, algo muito desejável, portanto, no âmbito escolar.

Por outro lado, havia o fato de que o próprio frei e seus confrades pertenciam a uma congregação que poderia ser chamada de modernizante e que de maneira nenhuma pretendia opor-se cegamente aos benefícios da ciência. Alguns indicativos dessa postura são o fato da revista Vozes de Petrópolis, por ele dirigida, apresentar-se, em seu subtítulo, como uma publicação "mensal, religiosa, científica e literária", prometendo, em seu primeiro editorial, que esta teria "caráter geral e não puramente religioso" e que traria "[...] artigos variados, que terão o cunho da atualidade. Nenhuma região da ciência e da técnica, da teoria e da prática será excluída do programa". (Vozes de Petrópolis, $1^{\circ}$ jul. 1907, p. 1).

Portanto, é provável que ao registrar e publicar, dias depois, a discussão ocorrida na reunião dos trabalhadores, o franciscano tenha tido tempo para pensar e decidir-se pela estratégia mais favorável para o embate que vinha travando. Sua decisão foi a de negar qualquer mérito ao ensino racionalista, associando-o, ao 
invés disso, à violência e ao assassinato, num discurso idêntico àquele que vinha sendo difundido pelo Estado e por outros grupos conservadores, criminalizando a militância e a pedagogia anarquistas. Ele seguiu essa linha de raciocínio não por desconhecimento, mas provavelmente por entender que este seria o caminho mais simples e eficiente para reforçar em sua assistência e em seus leitores a aversão ao pensamento ácrata e às Escolas Modernas. Foge às condições desta análise precisar o quão bem-sucedido o religioso logrou ser em seu intento. $\mathrm{O}$ que se pode afirmar, no entanto, é que a iniciativa da criação da Escola Moderna de Petrópolis teve vida curta, não ultrapassando o ano de 1913. (RODRIGUES, 1992, p 51-52).

Para finalizar, ressalte-se que a discussão aqui abordada exemplifica uma disputa bem mais ampla e profunda na qual estavam envolvidos grupos igualmente complexos e heterogêneos. As hostes católicas e anarquistas eram produtoras de grande quantidade de textos que não formavam um todo coerente, mas que, pelo contrário, eram fruto tanto de suas concepções de mundo e de educação, quanto das necessidades imediatas de respostas aos desafios presentes em suas militâncias. Nessa arena, a imprensa foi amplamente utilizada, tornando ainda mais necessário o esforço de escolarização que permitiria o ingresso de novas parcelas da população, aí incluídos os trabalhadores urbanos, à cultura letrada. Por outro lado, a expansão do universo escolar acabava por intensificar as batalhas políticas e ideológicas nas quais estavam em jogo tanto o controle da difusão do conhecimento quanto o controle das práticas pedagógicas a serem desenvolvidas.

\section{REFERÊNCIAS}

AMARAL, D. G. Confederação Católica do Trabalho: práticas discursivas e orientação católica para o trabalho em Belo Horizonte (1919-1930). Dissertação (Mestrado) Programa de Pós-Graduação em Ciências Sociais, PUC/Minas, Belo Horizonte, 2007.

BILHÃO, I. Identidade e Trabalho: uma história do operariado porto-alegrense (18981920). Londrina: EDUEL, 2008.

CARNEIRO, M. L. T. Livros Proibidos, ideias malditas. O DEOPS e as minorias silenciadas. São Paulo: FAPESP/Ateliê Editorial, 2002.

CARVALHO, J. M. Cidadania no Brasil: O longo caminho. Rio de Janeiro: Civilização Brasileira, 2001. 
CASTRO, R. C. de. Nem prêmio, nem castigo! A Escola Moderna como ação revolucionária dos sindicatos operários durante Primeira República (São Paulo, 1909-1919). Tese (Doutorado em Educação) - Universidade Estadual do Rio de Janeiro, Rio de Janeiro, 2014.

DALLABRIDA, N. Das escolas paroquiais à PUCS: República, catolização e escolarização. In: STEPHANOU, M.; BASTOS, M. H. C. (Org.). Histórias e memórias da educação no Brasil. Petrópolis: Vozes, 2005.

GALLO, S. Francisco Ferrer Guardia: o mártir da Escola Moderna. Pró-Posições, Campinas: Unicamp, v. 24, p. 241-251, 2013.

GALLO, S.; MORAES, J. D. de. Anarquismo e educação - A educação libertária na Primeira República. In: STEPHANOU, M.; BASTOS, M. H. C. (Org.). Histórias e memórias da educação no Brasil. Petrópolis: Vozes, 2005.

HERMANN, J. Religião e política no alvorecer da República: os movimentos de Juazeiro, Canudos e Contestado. In: FERREIRA, J.; DELGADO, L. de A. N. (Org.). O Brasil Republicano 1: o tempo do liberalismo excludente - da Proclamação da República à Revolução de 1930. Rio de Janeiro: Civilização Brasileira, 2003.

LUIZZETO, F. V. Utopias anarquistas. São Paulo: Brasiliense, 1987.

PAIVA, V. P. Educação popular e educação de adultos. São Paulo: Loyola, 1973.

PERES, F. A. Revisitando a trajetória de João Penteado: o discreto transgressor de limites. São Paulo, 1890-1940. Tese (Doutorado), Faculdade de Educação, Universidade de São Paulo, São Paulo, 2010.

RIEGELHAUPT, J. F. O significado religioso do anticlericalismo popular. Análise Social, v. XVIII, p. 1213-1230, 1982.

RODRIGUES, E. O anarquismo: na escola, no teatro, na poesia. Rio de Janeiro: Achiamé, 1992.

SANTOS, M. M. Frei Pedro Sinzig - O apóstolo da boa imprensa. In: SEMINÁRIO BRASILEIRO SOBRE LIVRO E HISTÓRIA EDITORIAL, I., 2004. Rio de Janeiro. Anais... Rio de Janeiro: Fundação Casa de Rui Barbosa, 8 a 11 nov. 2004.

SANTOS, M. M. Os Jardins Abençoados de um Franciscano - discurso sobre a leitura de Frei Pedro Sinzig: 1915-1923. Dissertação (Mestrado) - Programa de Pós-Graduação em História Social, Universidade de São Paulo, São Paulo, 2006.

SCHMIDT, B. A palavra como arma: uma polêmica na imprensa operária porto-alegrense em 1907. História em Revista, UFPEL: Pelotas, v. 6, p. 59-84, 2000.

SCHUELER, A. F. M. de; MAGALDI, A. M. B. de M. Educação escolar na Primeira República: memória, história e perspectivas de pesquisa. Tempo, v. 13, n. 26, p. 32-55, 2009. 
SILVA JR, A. L. O herói no movimento operário. In: OTERO, L. ELMIR, C. Mitos e heróis: construção de imaginários. Porto Alegre: Ed. da UFRGS, 1998.

SOUZA, J. J. V. de. Círculos Operários: a Igreja Católica e o mundo do trabalho no Brasil. Rio de Janeiro: UFRJ, 2002.

TRAGTENBERG, M. Francisco Ferrer e a pedagogia libertária. Educação e Sociedade - CEDES, Campinas, n. 1, p. 17-49, 1978.

UllmAN, J. C. La Semana Trágica. Estudio sobre las causas socioeconómicas del anticlericalismo en España (1898-1902). Barcelona: Ariel, 1972.

VALLADARES, E. Anarquismo e Anticlericalismo. São Paulo: Imaginário, 2000.

VELÁZQUEZ, P; VIÑAO, A. Un programa de educación popular: el legado de Ferrer Guardia y la Editorial Publicaciones de la Escuela Moderna (1901-1936). Educació $i$ Història: Revista d'Història de l'Educació, Societatd' Història de l'Educació dels Països de Llengua Catalana, n. 16, p. 79-104, 2010.

VENTURA, R. Estilo tropical: história cultural e polêmicas literárias no Brasil. São Paulo: Companhia das Letras, 1991.

VIÑAO, A. Alfabetização na sociedade e na história: vozes, palavras e textos. Porto Alegre: Artes Médicas, 1993.

ZORRILLA, E. M. Asociacionismo confesional en Valladolid: la asociación católica de escuelas y círculo de obreros, 1881-1914. Valladolid: Universidad de Valladolid, 1987.

Documentos consultados

A VOZ DO TRABALHADOR, Rio de Janeiro, $1^{\circ}$ jan. 1914.

O SINDICALISTA, Lisboa, 13 out. 1911.

RERUM NOVARUM, São Paulo, 1941.

VOZES DE PETRÓPOLIS, Petrópolis, RJ, 1º jul. 1907.

VOZES DE PETRÓPOLIS, $1^{\circ}$ nov. 1913. Encarte “Ferrer 'Mártir' ou 'patife'?”.

Texto recebido em 03 de outubro de 2015.

Texto aprovado em 28 de janeiro de 2016. 